\title{
Morphological Variation among Different Isolates of Colletotrichum gloeosporioides Isolated from Various Crops in Western Maharashtra, India
}

\author{
M.S. Bandgar ${ }^{1 *}$, B.G. Barhate ${ }^{2}$ and K.S. Raghuwanshi ${ }^{3}$ \\ Department of Plant Pathology and Agricultural Microbiology, \\ Mahatma PhuleKrishiVidyapeeth, Rahuri, Maharashtra (India) 413 722, India \\ *Corresponding author
}

\section{Key words}

\section{Colletotrichum} gloeosporioidesis, Conidia, Acervulus, Mycelium

Article Info

Accepted:

17 January 2018 Available Online: 10 February 2018

\section{A B S T R A C T}

Present investigation reveals the study of morphological variation among different isolates of Colletotrichum gloeosporioides isolated from various crops. Forty one diseased specimens were collected from different localities of Western Maharashtra and subjected to tissue isolation on PDA. Out of 41 specimens obtained from different hosts, 14 isolates from 14 various hosts were found to be pathogenic when inoculated on respective plant part. These 14 isolates were used for further study and further abbreviated as $\mathrm{Cg}-1$ to $\mathrm{Cg}-14$. Colletotrichum gloeosporioides isolated differed significantly in all morphological traits except the type of mycelium. Mycelium of all isolates was septate. Maximum average mycelial growth rate of $12.14 \mathrm{~mm} \mathrm{day}^{-1}$ was observed in isolates $\mathrm{Cg}-1$ and $\mathrm{Cg}-14$, isolated from pomegranate and sweet orange respectively. Almost all these 14 isolates were referred as fast growing. Isolates viz. Cg-7, Cg-9, Cg-10, Cg-11, Cg-12 and Cg-13 do not produce acervuli in culture. In rest of the 8 isolates, acervuli formation was noticed within 10-25 days after inoculation. The early development of acervuli after 10 days of inoculation was observed in $\mathrm{Cg}-3, \mathrm{Cg}-5$ and $\mathrm{Cg}-8 . \mathrm{Cg}-1$ from pomegranate was poor in acervuli formation ability and required more time (18-20 days). The maximum length of acervuli were recorded in $\mathrm{Cg}-2, \mathrm{Cg}-3$ and $\mathrm{Cg}-5(175 \mu \mathrm{m})$ respectively. While it was minimum $(137.67 \mu \mathrm{m})$ in $\mathrm{Cg}-4$ and was statistically undifferentiable from $\mathrm{Cg}-1, \mathrm{Cg}-6, \mathrm{Cg}-8$ and $\mathrm{Cg}-14$. The average size of acervuli ranged between $137.67-175.00 \times 87.67-170 \mu \mathrm{m}$. Extremely large acervuli was produced in culture of Cg-5 isolated from mango. There was a considerable variation in average length of the setae. The average maximum length of setae was $(87.67 \mu \mathrm{m})$ recorded in isolate $\mathrm{Cg}-8$, which was isolated from chilli. The shortest setae were observed in $\mathrm{Cg}-2$ and $\mathrm{Cg}-6$ having average length of $60.00 \mu \mathrm{m}$, isolated from custard apple and strawberry respectively. The average length of setae among all these isolates was recorded in between $60.00-87.67 \mu \mathrm{m}$. All these 14 isolates produced conidia in pure culture within 7 days after inoculation. The average length and width of conidia of $C$. gloeosporioides ranged between 10.00-12.33 X $3.00-4.33 \mu \mathrm{m}$ and this difference was statistically significant. Large sized conidia $(12.33 \mathrm{X} 4.33 \mu \mathrm{m})$ was recorded in $\mathrm{Cg}-8$, isolated from chilli. While that of small sized conidia $(10.00 \times 3.00 \mu \mathrm{m})$ were recorded in $\mathrm{Cg}-2$ and $\mathrm{Cg}-9$, isolated from custard apple and ginger respectively. The maximum L X B ratio (3.33) was observed in $\mathrm{Cg}-2$ and $\mathrm{Cg}-9$, both these isolates were from custard apple and ginger. While it was minimum (2.75) in Cg-14 i.e. isolated from sweet orange. There was great deal of variation in the colony characters within $C$. gloeosporioides isolates. The colony colour was the most variable factor and none of the isolate was found to be identical with each other. The most predominant colour was creamy white to gray with various intermediate shades. While in case of colony colour at reverse, most of the isolates had dark gray to black colour with slightly different shades. Out of 14 isolates, eight isolates (viz., $\mathrm{Cg}-3, \mathrm{Cg}-4$, $\mathrm{Cg}-6, \mathrm{Cg}-8, \mathrm{Cg}-9, \mathrm{Cg}-10, \mathrm{Cg}-13$ and Cg-14) had fluffy mycelium growth, while that of six isolates (viz., $\mathrm{Cg}-1, \mathrm{Cg}-2, \mathrm{Cg}-5, \mathrm{Cg}-7, \mathrm{Cg}-11$, and $\mathrm{Cg}-12$ ) had tight mycelium growth. Isolates (viz., Cg-1, Cg-2, Cg-3, $\mathrm{Cg}-4, \mathrm{Cg}-5, \mathrm{Cg}-10, \mathrm{Cg}-11$ and $\mathrm{Cg}-12)$ had entire margin with regular shape. Entire margin with irregular shape of colonies were noticed in the isolates $\mathrm{Cg}-7$ and $\mathrm{Cg}-8$ respectively. While that of $\mathrm{Cg}-6, \mathrm{Cg}-9, \mathrm{Cg}-13$ and $\mathrm{Cg}-14$ had undulate or wavy margin with irregular shaped colonies. 


\section{Introduction}

The Western Maharashtra region majorly contributes for the production of fruit, vegetable, cereal, flower, medicinal and ornamental crops. The production of these agricultural crops has many problems particularly, fungal diseases. Among these, anthracnose or fruit rot caused by Colletotrichum gloeosporioides is most destructive disease and known to cause great losses to the fruit growers in terms of both quality and quantity (Phoulivong et al., 2010). It causes anthracnose, die back, whither tip, shot hole, leaf blight and post harvest rots in many economically important crops such as cereals, pulses, vegetables, fruits, spices and cash crops. Colletotrichum gloeosporioides cause typical disease symptoms known as anthracnose, characterized by sunken necrotic tissue, produced in lesions on petioles, leaves, mummified inflorescences, flower bracts and on fruits (Dodd et al., 1992) and can acts as continuous sources of inoculums. The most significant damage of this fungus occurs upon its attack on fruiting stage (Baily et al., 1992). Under such circumstances, the nature of the C. gloeosporioides will be the decisive factor in the epidemic development. Therefore, investigation on the basic and applied aspects of population biology of $C$. gloeosporioides is the need of time. It is also necessary to understand how the existing population of the pathogen interacts with the emerging population of the host species and varieties. Similarly, behaviour of $C$. gloeosporioides under intensive management system in crops needs to be investigated in relation with fungicides commonly used as well as newly available. The different isolates of Colletotrichum gloeosporioides isolated from different host plants, shows variation in their morphological characters.

The ambiguous taxonomic status of Colletotrichum species has resulted in inaccurate identification which may cause practical problems in plant breeding and disease management. Hence there is great potential for augmentation of morphological characteristics for a better classification and identification system, such data will allow the development of proper, objective and automated identification techniques for Colletotrichum gloeosporioides.

Considering all these points the investigation on morphological variability was carried out.

\section{Materials and Methods}

The present investigation was carried out during August 2014 to December 2017 at Department of Plant Pathology and Agricultural Microbiology, PGI, M.P.K.V. Rahuri, 413 722. The material used and methods and procedures followed to investigate the morphological variability within the isolates of Colletotrichum gloeosporioides were as follows.

\section{Collection, isolation and pathogenicity}

\section{Collection of disease samples}

Diseased specimens from different crops in the form of infected fruits as well as leaves and shoots were periodically collected on the basis of symptoms from Western Maharashtra region in the state by personal visit. The details of the same are as described in Table 1.

\section{Isolation}

With exception of pomegranate fruits all other specimens were subjected to tissue isolation. Infected specimens showing typical anthracnose, leaf blight, fruit rot or die back symptoms were brought to laboratory, washed thoroughly with distilled water and dried in the folds of blotting paper. The diseased 
patches on the surface of leaf, fruit or shoot were cut in to pieces of about $1 \mathrm{sq} . \mathrm{cm}$ in such a way that the cut piece will carry enough diseased portions along with some healthy part. The cut pieces were surface sterilized with $0.5 \%$ sodium hypochlorite for $30 \mathrm{sec}$ followed by rinsing with three changes of distilled sterile water. The excess water on the surface of pieces was removed by placing them in the folds of pre sterilized blotting paper. Such pieces were then transferred aseptically on PDA previously poured in the petriplates. In each plate three pieces at equal distance were placed and such plates were incubated at $28^{\circ} \mathrm{C}$ temperature with $95 \% \mathrm{RH}$. After $48 \mathrm{hrs}$. of incubation, the plates were examined for development of visible mycelium growth. The typical growth around individual bit was transferred to PDA slant and incubated for 90-96 hrs. Temporary mounts were prepared to confirm the involvement of the fungus $C$. gloeosporioides. The growth obtained other than the desired fungus was discarded. In case of some fruit specimens showing pink-salmon coloured conidial growth on necrotic patches was directly transferred aseptically on the surface of PDA with the help of sterilized needle. Inoculated plates were inocubated at $28^{\circ} \mathrm{C}$ temperature and 95 per cent $\mathrm{RH}$ for $48 \mathrm{hrs}$. The distinct mycelial growth was aseptically transferred to PDA slant. The cultures of C. gloeosporioides obtained were subjected to serial dilution to get monoconidial pure cultures. Such cultures were maintained further for confirmation of the pathogenicity (Table 2).

\section{Pathogenicity}

For each isolates a separate pathogenicity test was carried out by detached leaf or fruit technique. The plant species and plant parts (i.e. fruits or leaves) from which actually the organism was isolated were used. $C$. gloeosporioides isolates from ginger, turmeric, garlic, jasmine (Mogra) and onion were inoculated on leaves of healthy plants of respective hosts in glasshouse.

While that of isolates from pomegranate, custard apple, papaya, guava, mango, strawberry, lime, chilli and sweet orange were inoculated on healthy fruits of respective hosts. Leaves or fruits were washed with tap water, air dried, surface disinfected with 0.1 $\%$ mercuric chloride solution one minute followed by thoroughly but gentle rinsing with sterilized water for three times to remove the traces of disinfectant and subjected to fine injury on abaxyl surface with the help of carborundum powder so as to facilitate the entry of the germ tube. Thereafter, the fruits were kept on flask or beaker $(100 \mathrm{ml})$ by inserting the fruit stalk in sterilized water, which is previousely filled in them. The fruits were covered with sterilized polythene bags.

It was done to provide 24 hours preinoculation incubation of fruits as suggested by Manandharet al., (1995). Next day the bags were removed and inoculation was made at the site of fruits. Seven to ten days old culture of respective isolate showing abundant salmon coloured conidial masses was added with little quantity of sterile water and conidial masses were separated from the culture with the help of scalpel. The conidial load in the suspension was adjusted to $10^{6}$ conidial $\mathrm{ml}^{-1}$. Such freshly prepared suspension was automised on the injured surface of leaves or fruits by micro-droplet inoculation technique (MDIT). A fine wet cotton swab was then placed on the inoculated portion of the leaves or fruits. A suitable control was maintained separately at every time wherein instead of conidial suspension, sterilized water was sprayed on the injured leaf or fruit. A set of inoculated plants was maintained in the glasshouse as well as in moisture chamber according to the inoculated plant parts i. e. leaves and fruits respectively, 
at $27^{\circ} \mathrm{C}$ with more than 90 per cent $\mathrm{RH}$ for two weeks.

Reisolation was made from inoculated surface upon development of symptoms. The cultures obtained upon reisolation were compared with the respective original culture. Isolates fulfilling the pathogenicity test were accessed according to host. $\mathrm{Cg}$ was the common prefix representing the test fungus. All cultures were maintained in duplicate sets and stored in the refrigerator at temperature of $6-8^{0} \mathrm{C}$. All cultures were periodically sub cultured every after two months and maintained during the course of investigation.

\section{Identification}

Isolates fulfilling the pathogenicity test were tentatively identified on the basis of morphological and cultural characters with the help of available literature.

\section{Variation in morphological characters}

To study the morphological variation within the isolates, all isolates were grown on PDA for seven to ten days at $28^{\circ} \mathrm{C}$ with 90 per cent humidity. Temporary mounts of different fungal structures viz., mycelium, acervuli, setae and conidia were prepared and observed under light microscope at magnification of 45 $\mathrm{X}$.

The filarmicrometer was calibrated with the help of stage micrometer prior to measurements. Measurements of each structure were recorded from five to eight slides at three microscopic fields randomly. For conidial measurements, 50 observations were taken while for all other structures, 25 observations were recorded and mean value was calculated.

Observations on acervuli measurements of different isolates were recorded as and when they were formed within 25-45 days. The observations on morphological measurements of different structures were further analysed collectively by agglomerative hierarchial cluster analysis (Aldenderfer and Blashfield, 1984). Observations on colony morphology viz., colour, colour at reverse, distinct feature, margin and shape were recorded by growing all isolates of C. gloeosporioides on PDA for seven days at $28^{\circ} \mathrm{C}$ with 90 per cent humidity. Variation in these colony characters was determined qualitatively. The colour ratings were made with the help of Munsell's colour chart and accordingly isolates were grouped.

Growth measurements were recorded at right angle from the reverse side of the plate with the help of scale and expressed as average growth rate in mm after $3^{\text {rd }}, 5^{\text {th }}$ and $7^{\text {th }}$ days of incubation for each isolate in three replications. The data obtained was analysed by using Completely Randomized Design (CRD).

\section{Results and Discussion}

\section{Isolation}

In the present study, $C$. gloeosporioides was isolated in the laboratory on PDA. Isolations were made from fruit samples of pomegranate, custard apple, papaya, guava, mango, strawberry, acid lime, chilli and sweet orange which were collected from different parts of the Western Maharashtra. Similarly, C. gloeosporioides was also recovered from leaf samples of ginger, turmeric, garlic, jasmine and onion. C. gloeosporioides initially produced white profuse cottony growth around the host tissue placed for isolation within $72 \mathrm{hrs}$ of incubation which later turned gray with formation of acervuli in some of the isolates within next $72 \mathrm{hrs}$. These findings are in similar lines as those reported by Hasabnis (1984), Korade et al., (2001). 


\section{Pathogenicity}

Fruits of pomegranate, custard apple, papaya, guava, mango, strawberry, acid lime, chilli and sweet orange expressed initiation of typical fruit rot symptoms at the point of inoculation within 3-6 days after inoculation. Large necrotic round to irregular lesions developed in further seven to ten days. Symptoms development was rapid in pomegranate, custard apple, guava, mango and chilli fruits (72-90 hrs) followed by papaya, strawberry, acid lime and sweet orange (105 hrs). However, symptoms initiation was comparatively late in ginger, turmeric, garlic, jasmine and onion. It was observed that development of symptoms upon artificial inoculation was comparatively rapid when fruits were inoculated in comparison with the inoculation on leaves.

These results are in confirmation with the findings of Talhinhas et al., (2005). They have proved the pathogenicity of $C$. accutatum and $C$. gloeosporioides with a representative set of isolates using fruits of 11 different olive cultivars and 'Camarosa' strawberry and obtained symptoms after 7 and 11 days on strawberry and olive fruits respectively. However, Hasabnis (1984) reported a period of $48-72$ hrs for development of artificial infection of $C$. gloeosporioides. In present study, it took a minimum period of $72 \mathrm{hrs}$ for getting initial infection on either fruit or leaf which was inoculated artificially (Table 3).

\section{Identification}

The tentative identification of all 14 isolates was made on the basis of conidial morphology and cultural characters.

\section{Variation in the morphological characters}

All these 14 isolates of C. gloeosporioides were produced the septate mycelium. The maximum average growth rate of $12.14 \mathrm{~mm}$ day ${ }^{-1}$ was observed in isolates $\mathrm{Cg}-1$ and $\mathrm{Cg}-14$ and it was statistically on par with isolates viz., $\mathrm{Cg}-7$ and $\mathrm{Cg}-11$ followed by $\mathrm{Cg}-2, \mathrm{Cg}-3$, $\mathrm{Cg}-4, \mathrm{Cg}-5, \mathrm{Cg}-6, \mathrm{Cg}-8, \mathrm{Cg}-9, \mathrm{Cg}-10, \mathrm{Cg}-12$ and $\mathrm{Cg}-13$. These isolates were referred as fast growing. Similar trends in the colony morphology was reported earlier byAbnang $e t$ al., (2006) who classified isolates of $C$. gloeosporioides based on colony colour and growth rate and categorized them into four groups. Similar results were also reported by Mathur et al., (2001) and Lopez and Lucas (2010) (Table 4).

\section{Acervuli}

Out of 14 isolates under study, 8 isolates produced acervuli in culture. Isolates viz. $\mathrm{Cg}$ 7, Cg-9, Cg-10, Cg-11, Cg-12 and Cg-13 do not produce acervuli in culture. In rest of the 8 isolates, acervuli formation was noticed within 10-25 days after inoculation. The early development of acervuli after 10 days of inoculation was observed in $\mathrm{Cg}-3, \mathrm{Cg}-5$ and $\mathrm{Cg}-8$. Acervuli formation was noticed within 10-25 days after inoculation.

The early development of acervuli after ten days of inoculation was observed in $\mathrm{Cg}-3$, $\mathrm{Cg}-5$ and $\mathrm{Cg}-8$.

The acervuli were formed profusely and regularly during the course of study with these isolates and therefore these isolates were referred as profuse acervuli producers. $\mathrm{Cg}-1$ from pomegranate was poor in acervuli formation ability and required more time (1820 days) to form acervuli. Remaining isolates viz., Cg-2, Cg-4, Cg-6 and Cg-14 formed acervuli less frequently when grown on PDA. In general the shape of acervuli was elliptical globose to irregular. The colour of acervuli was light brown to dark in general. The differences in acervuli measurements were 
statistically significant.

The maximum length of acervuli were recorded in $\mathrm{Cg}-2, \mathrm{Cg}-3$ and $\mathrm{Cg}-5(175 \mu \mathrm{m})$ respectively. While it was minimum (137.67 $\mu \mathrm{m})$ in $\mathrm{Cg}-4$ and was statistically undifferentiable from $\mathrm{Cg}-1, \mathrm{Cg}-6, \mathrm{Cg}-8$ and $\mathrm{Cg}-14$. The average size of acervuli ranged between $137.67-175.00 \times 87.67-170 \mu \mathrm{m}$. Extremely large acervuli was produced in culture of $\mathrm{Cg}-5$ isolated from mango. The range of acervuli dimensions in the present study is comparatively narrow when compared to that of acervuli measurements reported earlier by Joshi (2008). While studying the morphological variation within C. gloeosporioides isolates infecting custard apple. He has mentioned that the average size of acervuli ranged between $104.04-412.92$ $\mu \mathrm{m}$ X $54.36-147.80 \mu \mathrm{m}$. These findings are in conformity with Gaikwad and Sawant (2005) (Table 5).

\section{Length of setae}

Out of 14 isolates, eight isolates could produce setae as an integral part of acervulus. Setae differed with respect to colour, shape and measurements. Light brown to dark brown coloured setae were predominantly observed in all isolates. There was a considerable variation within the $C$. gloeosporioides isolates in average length of the setae. The average maximum length of setae was $(87.67 \mu \mathrm{m})$ recorded in isolate $\mathrm{Cg}-8$, which was isolated from chilli. The shortest setae were observed in $\mathrm{Cg}-2$ and $\mathrm{Cg}-6$ having average length of $60.00 \mu \mathrm{m}$, isolated from custard apple and strawberry respectively. The average length of setae among all these isolates was recorded in between 60.00 $87.67 \mu \mathrm{m}$.

These findings agree with Rohana et al., (2006) who studied the comparative characterization of seven isolates of $C$. gloeosporioides and stated the formation of sclerotia in one isolate but setae formation was not recorded. However, the findings in relation with setae morphology are in conformity with those recorded by Gaikwad and Sawant (2005) and Joshi (2008) (Table $6)$.

\section{Conidia}

All these 14 isolates produced conidia in pure culture within 7 days after inoculation. In general, conidia were hyaline, unicellular, cylindrical to allantoidal with an obtuse apex. Conidia of all isolates were more or less identical in shape. The average length and width of conidia of $C$. gloeosporioides ranged between10.00-12.33 X 3.00-4.33 $\mu \mathrm{m}$ and this difference was statistically significant.

Large sized conidia $(12.33 \mathrm{X} 4.33 \mu \mathrm{m})$ was recorded in $\mathrm{Cg}-8$, isolated from chilli and it was on par with $\mathrm{Cg}-1$. While that of small sized conidia $(10.00 \quad \mathrm{X} 3.00 \mu \mathrm{m})$ were recorded in $\mathrm{Cg}-2$ and $\mathrm{Cg}-9$, isolated from custard apple and ginger respectively. The maximum $\mathrm{L} X \mathrm{~B}$ ratio (3.33) was observed in $\mathrm{Cg}-2$ and $\mathrm{Cg}-9$, both these isolates were from custard apple and ginger. While it was minimum (2.75) in $\mathrm{Cg}-14$ i.e. isolated from sweet orange.

The above findings with respect to conidial length and width are analogous with those reported by Gaikwad and Sawant (2005). They have found that isolate $\mathrm{Cg} 6413$ produced large sized conidia measuring 12.26 $\mu \mathrm{m}$ in length, while conidia of isolate $\mathrm{Cg}$ 0818 had maximum width of $4.78 \mu \mathrm{m} . \mathrm{Cg}$ 0914 produced shortest conidia having the length of $9.96 \mu \mathrm{m}$.

Highest L : B ratio of 3.94 was observed in Cg 06413, while it was lowest (2.41) in Cg 0736. Shape of most of the conidia was reported to be cylindrical but sometimes oval to cylindrical forms were also observed (Table 7). 
Table.1 Collection of disease samples collected from different crops in Western Maharashtra

\begin{tabular}{|c|c|c|c|c|c|}
\hline \multirow[t]{2}{*}{ Sr. No. } & \multirow[t]{2}{*}{ Name of crop } & \multirow{2}{*}{ Host part } & \multicolumn{3}{|c|}{ Location } \\
\hline & & & Place/Village & Tahsil & District \\
\hline 01 & Pomegranate & Fruit & Akolevasud & Sangola & Solapur \\
\hline 02 & Papaya & Fruit & Akluj & Malshiras & Solapur \\
\hline 03 & Guava & Fruit & Rahuri & Rahuri & A.nagar \\
\hline 04 & Strawberry & Fruit & Bhilar & Mahableshwar & Satara \\
\hline 05 & Custard apple & Fruit & Jejuri & Purandar & Pune \\
\hline 06 & Papaya & Fruit & Shirbavi & Sangola & Solapur \\
\hline 07 & Mango & Fruit & Kothali & Shirol & Kolhapur \\
\hline 08 & Strawberry & Fruit & Panchgani & Mahableshwar & Satara \\
\hline 09 & Acid lime & Fruit & Varvand & Daund & Pune \\
\hline 10 & Pomegranate & Fruit & Mahud & Sangola & Solapur \\
\hline 11 & Custard apple & Fruit & Lonarwadi & Pandharpur & Solapur \\
\hline 12 & Chilli & Fruit & Tawadi & Phaltan & Satara \\
\hline 13 & Guava & Fruit & Aasu & Phaltan & Satara \\
\hline 14 & Ginger & Leaf & Pusegoan & Khatav & Satara \\
\hline 15 & Papaya & Fruit & Rede & Malshiras & Solapur \\
\hline 16 & Turmeric & Leaf & Sangawade & Karveer & Kolhapur \\
\hline 17 & Mango & Fruit & Khanapur & Bhor & Pune \\
\hline 18 & Garlic & Leaf & Vidani & Phaltan & Satara \\
\hline 19 & Maize & Leaf & Paniv & Malshiras & Solapur \\
\hline 20 & Jasmine & Leaf & Pandare & Baramati & Pune \\
\hline 21 & Turmeric & Leaf & Bujgoan & Miraj & Sangli \\
\hline 22 & Strawberry & Fruit & Mahableshwar & Mahableshwar & Satara \\
\hline 23 & Sweet orange & Fruit & Kashti & Shrigonda & A. nagar \\
\hline 24 & Papaya & Fruit & Rajale & Phaltan & Satara \\
\hline 25 & Mango & Fruit & Untwadi & Jat & Sangli \\
\hline 26 & Jasmine & Leaf & Sangavi & Phaltan & Satara \\
\hline 27 & Ginger & Leaf & Amnapur & Palus & Sangli \\
\hline 28 & Custard apple & Fruit & Saswad & Purandar & Pune \\
\hline 29 & Acid lime & Fruit & Kashti & Shrigonda & A. nagar \\
\hline 30 & Mango & Fruit & Rahuri & Rahuri & A. nagar \\
\hline 31 & Chilli & Fruit & Songoan & Phaltan & Satara \\
\hline 32 & Guava & Fruit & Nira-Wagaj & Baramati & Pune \\
\hline 33 & Ginger & Leaf & K.Digras & Miraj & Sangli \\
\hline 34 & Turmeric & Leaf & K.Digras & Miraj & Sangli \\
\hline 35 & Onion & Leaf & Nandurshingote & Sinnar & Nashik \\
\hline 36 & Turmeric & Leaf & Nandani & Shirol & Kolhapur \\
\hline 37 & Garlic & Leaf & Mirgoan & Phaltan & Satara \\
\hline 38 & Onion & Leaf & Dahiwadi & Man & Satara \\
\hline 39 & Sweet orange & Fruit & Mirajgoan & Karjat & A. nagar \\
\hline 40 & Maize & Leaf & Tavashi & Baramati & Pune \\
\hline 41 & Pomegranate & Fruit & Sonake & Pandharpur & Solapur \\
\hline
\end{tabular}


Table.2 Isolates of $C$. gloeosporioides collected from different hosts from Western Maharashtra region

\begin{tabular}{|c|c|c|c|c|c|}
\hline \multirow[t]{2}{*}{ Isolate No. } & \multirow[t]{2}{*}{ Name of the crop } & \multirow[t]{2}{*}{ Host part } & \multicolumn{3}{|c|}{ Location } \\
\hline & & & $\begin{array}{c}\text { Place/ } \\
\text { Village }\end{array}$ & Tahasil & District \\
\hline Cg-1 & Pomegranate & Fruit & Akolevasud & Sangola & Solapur \\
\hline Cg-2 & Custard apple & Fruit & Saswad & Purandar & Pune \\
\hline Cg-3 & Papaya & Fruit & Akluj & Malshiras & Solapur \\
\hline $\mathrm{Cg}-4$ & Guava & Fruit & Rahuri & Rahuri & A.nagar \\
\hline $\mathrm{Cg}-5$ & Mango & Fruit & Rahuri & Rahuri & A.nagar \\
\hline Cg-6 & Strawberry & Fruit & Mahableshwar & Mahableshwar & Satara \\
\hline Cg-7 & Lime & Fruit & Kashti & Shrigonda & A.nagar \\
\hline Cg-8 & Chilli & Fruit & Tawadi & Phaltan & Satara \\
\hline Cg-9 & Ginger & Leaf & Amnapur & Palus & Sangli \\
\hline Cg-10 & Turmeric & Leaf & Sangawade & Karveer & Kolhapur \\
\hline Cg-11 & Garlic & Leaf & Vidani & Phaltan & Satara \\
\hline Cg-12 & Jasmine & Leaf & Pandare & Baramati & Pune \\
\hline $\mathrm{Cg}-13$ & Onion & Leaf & Nandurshingote & Sinnar & Nashik \\
\hline $\mathrm{Cg}-14$ & Sweet orange & Fruit & Kashti & Shrigonda & A.nagar \\
\hline
\end{tabular}

Table.4 Variability in mycelium growth rate among different isolates of $C$. gloeosporioides collected from different crops in Western Maharashtra

\begin{tabular}{|c|c|c|c|c|c|}
\hline \multirow{2}{*}{$\begin{array}{l}\text { Sr. } \\
\text { No. }\end{array}$} & \multirow[t]{2}{*}{ Isolate } & \multirow{2}{*}{$\begin{array}{c}\text { Mycelium } \\
\text { (Septate/Aseptate) }\end{array}$} & \multicolumn{3}{|c|}{ Mycelial growth rate $(\mathrm{mm})$ per day } \\
\hline & & & $3^{\text {rd }}$ day & $5^{\text {th }}$ day & $7^{\text {th }}$ day \\
\hline 01 & $\mathrm{Cg}-1$ & Septate & 33.00 & 60.00 & 85.00 \\
\hline 02 & $\mathrm{Cg}-2$ & Septate & 29.00 & 55.00 & 80.00 \\
\hline $\mathbf{0 3}$ & $\mathrm{Cg}-3$ & Septate & 30.00 & 58.00 & 80.00 \\
\hline 04 & $\mathrm{Cg}-4$ & Septate & 30.00 & 59.00 & 80.00 \\
\hline 05 & $\mathrm{Cg}-5$ & Septate & 30.00 & 60.00 & 80.00 \\
\hline 06 & $\mathrm{Cg}-6$ & Septate & 28.00 & 54.00 & 80.00 \\
\hline 07 & $\mathrm{Cg}-7$ & Septate & 30.00 & 60.00 & 84.00 \\
\hline 08 & $\mathrm{Cg}-8$ & Septate & 30.00 & 54.00 & 80.00 \\
\hline 09 & $\mathrm{Cg}-9$ & Septate & 28.00 & 55.00 & 80.00 \\
\hline 10 & $\mathrm{Cg}-10$ & Septate & 29.00 & 55.00 & 80.00 \\
\hline 11 & $\mathrm{Cg}-11$ & Septate & 30.00 & 54.00 & 82.00 \\
\hline 12 & $\mathrm{Cg}-12$ & Septate & 28.00 & 56.00 & 80.00 \\
\hline 13 & $\mathrm{Cg}-13$ & Septate & 28.00 & 55.00 & 80.00 \\
\hline 14 & $\mathrm{Cg}-14$ & Septate & 30.00 & 60.00 & 85.00 \\
\hline \multicolumn{3}{|c|}{ SE ( \pm$)$} & 0.53 & 0.49 & 0.39 \\
\hline \multicolumn{3}{|c|}{ CD at $1 \%$} & 2.09 & 1.90 & 1.56 \\
\hline
\end{tabular}


Table.3 Pathogenicity symptoms produced by $C$. gloeosporioides isolates collected from different crops in Western Maharashtra

\begin{tabular}{|c|c|c|c|}
\hline $\begin{array}{l}\text { Isolate } \\
\text { code }\end{array}$ & Crop & Symptoms & $\begin{array}{l}\text { No. of days } \\
\text { required }\end{array}$ \\
\hline $\mathrm{Cg}-1$ & Pomegranate & $\begin{array}{l}\text { Rotting was noticed from fruit end portion resulting } \\
\text { into dark brown to black in colour. }\end{array}$ & $8-9$ \\
\hline $\mathrm{Cg}-2$ & Custard apple & $\begin{array}{l}\text { Large necrotic round to irregular lesions were } \\
\text { formed on fruits showing brown colour. }\end{array}$ & $7-8$ \\
\hline $\mathrm{Cg}-3$ & Papaya & $\begin{array}{l}\text { Lesions were observed, which began as dark brown, } \\
\text { punctate, circular to irregular spots of }<1.5 \mathrm{~mm} \text { in } \\
\text { diameter, often with distinctly graycenters. }\end{array}$ & $7-8$ \\
\hline $\mathrm{Cg}-4$ & Guava & $\begin{array}{l}\text { Lesions appeared as dark brown irregular and that } \\
\text { become sunken on the rind tissues. }\end{array}$ & $7-8$ \\
\hline $\mathrm{Cg}-5$ & Mango & $\begin{array}{l}\text { Dark brown to black coloured spots were observed, } \\
\text { which later coalesce to form sunken patches. }\end{array}$ & $7-8$ \\
\hline $\mathrm{Cg}-6$ & Strawberry & $\begin{array}{l}\text { Brown spherical depressed spots occurred in } \\
\text { scattered form on the pericarp. In advanced stage, } \\
\text { spots coalesced to form necrotic rotten patches. }\end{array}$ & $7-8$ \\
\hline $\mathrm{Cg}-7$ & Acid lime & $\begin{array}{l}\text { Spots may appear as dark brown irregular and that } \\
\text { become sunken on the rind tissues. }\end{array}$ & $8-9$ \\
\hline $\mathrm{Cg}-8$ & Chilli & $\begin{array}{l}\text { Observed typical anthracnose symptoms including } \\
\text { sunken necrotic tissues, with concentric rings of } \\
\text { acervuli on Chilli fruits. }\end{array}$ & $7-8$ \\
\hline Cg-9 & Ginger & $\begin{array}{l}\text { Brown spots were observed, which later turns } \\
\text { ellipsoidal or spindle shaped with halo. The affected } \\
\text { leaves eventually turn brown and results in dry rot. } \\
\text { Also this leaf spot characterized with small round to } \\
\text { oval, light yellow spots on leaves and leaf sheaths, } \\
\text { which gradually increase in size and coalesce to form } \\
\text { large discoloured areas. The infected areas often dry } \\
\text { up at the center, forming shot holes. }\end{array}$ & $7-8$ \\
\hline Cg-10 & Turmeric & $\begin{array}{l}\text { Brown spots were noticed on the upper surface of the } \\
\text { young leaves, spots are irregular in shape and white } \\
\text { or grey in the centre. Later, two or more spots may } \\
\text { coalesce and formed an irregular patch covering } \\
\text { almost the whole leaf. }\end{array}$ & $8-9$ \\
\hline Cg-11 & Garlic & $\begin{array}{l}\text { Observed typical anthracnose symptoms including } \\
\text { sunken necrotic tissues on the leaves. }\end{array}$ & $9-10$ \\
\hline Cg-12 & Jasmine & $\begin{array}{l}\text { Observed the anthracnose symptoms on leaves. The } \\
\text { spots were dark gray and mostly irregular shaped. }\end{array}$ & $9-10$ \\
\hline Cg-13 & Onion & $\begin{array}{l}\text { Observed typical anthracnose symptoms including } \\
\text { sunken necrotic tissues on the leaves. }\end{array}$ & $9-10$ \\
\hline Cg-14 & Sweet orange & $\begin{array}{l}\text { Spots may appeared as dark brown irregular and that } \\
\text { become sunken on the rind tissues. }\end{array}$ & $7-8$ \\
\hline
\end{tabular}


Table.5 Variability in acervuli among different isolates of $C$. gloeosporioides collected from different crops in Western Maharashtra

\begin{tabular}{|c|c|c|c|c|}
\hline $\begin{array}{l}\text { Sr. } \\
\text { No. }\end{array}$ & Isolates & $\begin{array}{c}\text { Acervuli } \\
\text { (Present/ } \\
\text { Absent) }\end{array}$ & $\begin{array}{l}\text { Acervuli length } \\
\qquad(\mu \mathrm{m})\end{array}$ & $\begin{array}{l}\text { Acervuli width } \\
\qquad(\mu \mathrm{m})\end{array}$ \\
\hline 01 & $\mathrm{Cg}-1$ & Present & 150.00 & 100.00 \\
\hline 02 & $\mathrm{Cg}-2$ & Present & 175.00 & 112.67 \\
\hline 03 & $\mathrm{Cg}-3$ & Present & 175.00 & 118.00 \\
\hline 04 & $\mathrm{Cg}-4$ & Present & 137.67 & 87.67 \\
\hline 05 & $\mathrm{Cg}-5$ & Present & 175.00 & 170.00 \\
\hline 06 & $\mathrm{Cg}-6$ & Present & 170.00 & 100.00 \\
\hline 07 & $\mathrm{Cg}-7$ & Absent & 00.00 & 00.00 \\
\hline 08 & $\mathrm{Cg}-8$ & Present & 162.67 & 95.00 \\
\hline 09 & $\mathrm{Cg}-9$ & Absent & 00.00 & 00.00 \\
\hline 10 & $\mathrm{Cg}-10$ & Absent & 00.00 & 00.00 \\
\hline 11 & $\mathrm{Cg}-11$ & Absent & 00.00 & 00.00 \\
\hline 12 & $\mathrm{Cg}-12$ & Absent & 00.00 & 00.00 \\
\hline 13 & $\mathrm{Cg}-13$ & Absent & 00.00 & 00.00 \\
\hline 14 & $\mathrm{Cg}-14$ & Present & 140.00 & 90.00 \\
\hline \multicolumn{3}{|c|}{ SE $( \pm)$} & 0.39 & 0.25 \\
\hline \multicolumn{3}{|c|}{ CD at $1 \%$} & 1.55 & 0.99 \\
\hline
\end{tabular}

Table.6 Variability in length of setae among different isolates of $C$. gloeosporioides collected from different crops in Western Maharashtra

\begin{tabular}{|c|c|c|c|}
\hline $\begin{array}{l}\text { Sr. } \\
\text { No. }\end{array}$ & Isolates & $\begin{array}{c}\text { Setae } \\
\text { (Present/ Absent) }\end{array}$ & Length $(\mu \mathrm{m})$ \\
\hline 01 & Cg-1 & Present & 61.67 \\
\hline 02 & $\mathrm{Cg}-2$ & Present & 60.00 \\
\hline 03 & $\mathrm{Cg}-3$ & Present & 62.00 \\
\hline 04 & $\mathrm{Cg}-4$ & Present & 62.67 \\
\hline 05 & $\mathrm{Cg}-5$ & Present & 61.00 \\
\hline 06 & $\mathrm{Cg}-6$ & Present & 60.00 \\
\hline 07 & $\mathrm{Cg}-7$ & Absent & 00.00 \\
\hline 08 & $\mathrm{Cg}-8$ & Present & 87.67 \\
\hline 09 & $\mathrm{Cg}-9$ & Absent & 00.00 \\
\hline 10 & $\mathrm{Cg}-10$ & Absent & 00.00 \\
\hline 11 & $\mathrm{Cg}-11$ & Absent & 00.00 \\
\hline 12 & $\mathrm{Cg}-12$ & Absent & 00.00 \\
\hline 13 & $\mathrm{Cg}-13$ & Absent & 00.00 \\
\hline 14 & $\mathrm{Cg}-14$ & Present & 64.00 \\
\hline \multicolumn{3}{|c|}{ SE ( $( \pm)$} & 0.34 \\
\hline \multicolumn{3}{|c|}{ CD at $1 \%$} & 1.34 \\
\hline
\end{tabular}


Table.7 Variability in conidia among different isolates of $C$. gloeosporioides collected from different crops in Western Maharashtra

\begin{tabular}{|c|c|c|c|c|}
\hline \multirow{2}{*}{$\begin{array}{l}\text { Sr. } \\
\text { No. }\end{array}$} & \multirow[t]{2}{*}{ Isolates } & \multirow[t]{2}{*}{ Shape of Conidia } & \multicolumn{2}{|c|}{ Size of conidia } \\
\hline & & & Length $(\mu \mathrm{m})$ & Width $(\mu \mathrm{m})$ \\
\hline 01 & $\mathrm{Cg}-1$ & \multirow{14}{*}{$\begin{array}{c}\text { Hyaline, Unicellular, } \\
\text { Cylindrical with an } \\
\text { obtuse apex. }\end{array}$} & 12.33 & 4.00 \\
\hline $\mathbf{0 2}$ & $\mathrm{Cg}-2$ & & 10.00 & 3.00 \\
\hline 03 & $\mathrm{Cg}-3$ & & 10.67 & 3.33 \\
\hline 04 & $\mathrm{Cg}-4$ & & 10.33 & 3.67 \\
\hline 05 & $\mathrm{Cg}-5$ & & 11.33 & 4.00 \\
\hline 06 & $\mathrm{Cg}-6$ & & 11.00 & 3.33 \\
\hline $\mathbf{0 7}$ & $\mathrm{Cg}-7$ & & 10.00 & 3.33 \\
\hline 08 & $\mathrm{Cg}-8$ & & 12.33 & 4.33 \\
\hline 09 & $\mathrm{Cg}-9$ & & 10.00 & 3.00 \\
\hline 10 & $\mathrm{Cg}-10$ & & 10.67 & 3.33 \\
\hline 11 & $\mathrm{Cg}-11$ & & 11.00 & 3.67 \\
\hline 12 & $\mathrm{Cg}-12$ & & 11.33 & 4.00 \\
\hline 13 & $\mathrm{Cg}-13$ & & 10.33 & 3.67 \\
\hline 14 & $\mathrm{Cg}-14$ & & 11.00 & 4.00 \\
\hline \multicolumn{3}{|c|}{ SE $( \pm)$} & 0.36 & 0.33 \\
\hline \multicolumn{3}{|c|}{ CD at $1 \%$} & 1.44 & 1.31 \\
\hline
\end{tabular}

Table.8 Variability in colony characters among different isolates of C. gloeosporioides collected from different crops in Western Maharashtra

\begin{tabular}{|c|c|c|c|c|c|c|}
\hline $\begin{array}{l}\text { Sr. } \\
\text { No. }\end{array}$ & Isolates & Colour & $\begin{array}{l}\text { Colours at } \\
\text { reverse }\end{array}$ & Distinct feature & Margin & Shape \\
\hline 01 & $\mathrm{Cg}-1$ & $\begin{array}{c}\text { Creamy } \\
\text { white to } \\
\text { Gray }\end{array}$ & Dark gray & $\begin{array}{l}\text { Tight mycelium growth with compact } \\
\text { colony. }\end{array}$ & Entire & Regular \\
\hline 02 & $\mathrm{Cg}-2$ & $\begin{array}{l}\text { Creamy } \\
\text { white to } \\
\text { Dark gray }\end{array}$ & $\begin{array}{l}\text { Dark gray to } \\
\text { black }\end{array}$ & $\begin{array}{l}\text { Tight mycelium growth with compact } \\
\text { colony and salmon concentric rings. }\end{array}$ & Entire & Regular \\
\hline 03 & $\mathrm{Cg}-3$ & $\begin{array}{l}\text { Pinkish } \\
\text { gray to } \\
\text { Dark gray }\end{array}$ & $\begin{array}{l}\text { Dark gray to } \\
\text { black }\end{array}$ & $\begin{array}{l}\text { Fluffy mycelium, partially } \\
\text { submerged growth. }\end{array}$ & Entire & Regular \\
\hline 04 & $\mathrm{Cg}-4$ & $\begin{array}{c}\text { Dark gray } \\
\text { to black } \\
\text { with } \\
\text { white } \\
\text { islands }\end{array}$ & $\begin{array}{l}\text { Black with } \\
\text { salmon patches }\end{array}$ & $\begin{array}{c}\text { Fluffy mycelium growth with } \\
\text { somewhat loose sub aerial hyphae. }\end{array}$ & Entire & Regular \\
\hline 05 & $\mathrm{Cg}-5$ & Dark gray & Gray to black & $\begin{array}{l}\text { Tight mycelium growth with compact } \\
\text { colony and salmon concentric rings. }\end{array}$ & Entire & Regular \\
\hline 06 & $\mathrm{Cg}-6$ & $\begin{array}{l}\text { Creamy } \\
\text { white }\end{array}$ & Creamy yellow & $\begin{array}{l}\text { Fluffy mycelium with profusely } \\
\text { growing dense aerial cottony growth. }\end{array}$ & $\begin{array}{l}\text { Undulate/ } \\
\text { Wavy }\end{array}$ & Irregular \\
\hline
\end{tabular}




\begin{tabular}{|c|c|c|c|c|c|c|}
\hline 07 & $\mathrm{Cg}-7$ & $\begin{array}{l}\text { White to } \\
\text { light gray }\end{array}$ & $\begin{array}{l}\text { Creamy yellow } \\
\text { with salmon } \\
\text { patches }\end{array}$ & Tight mycelium with flat growth. & Entire & Irregular \\
\hline 08 & $\mathrm{Cg}-8$ & Dark gray & $\begin{array}{l}\text { Black with } \\
\text { salmon patches }\end{array}$ & $\begin{array}{l}\text { Fluffy mycelium growth with dense } \\
\text { aerial hyphae. }\end{array}$ & Entire & Irregular \\
\hline 09 & $\mathrm{Cg}-9$ & Dark gray & Black gray & $\begin{array}{c}\text { Fluffy mycelium with profusely } \\
\text { aerial growth. }\end{array}$ & $\begin{array}{l}\text { Undulate/ } \\
\text { Wavy }\end{array}$ & Irregular \\
\hline 10 & $\mathrm{Cg}-10$ & $\begin{array}{l}\text { Whitish } \\
\text { gray }\end{array}$ & $\begin{array}{l}\text { Dark gray with } \\
\text { creamy center }\end{array}$ & Fluffy mycelium with flat growth. & Entire & Regular \\
\hline 11 & $\mathrm{Cg}-11$ & $\begin{array}{l}\text { Creamy } \\
\text { white }\end{array}$ & Creamy yellow & Tight mycelium with flat growth. & Entire & Regular \\
\hline 12 & $\mathrm{Cg}-12$ & $\begin{array}{l}\text { White to } \\
\text { light gray }\end{array}$ & Creamy yellow & Tight mycelium with flat growth. & Entire & Regular \\
\hline 13 & $\mathrm{Cg}-13$ & $\begin{array}{l}\text { Creamy } \\
\text { white to } \\
\text { light gray }\end{array}$ & $\begin{array}{l}\text { Black with } \\
\text { salmon patches }\end{array}$ & $\begin{array}{l}\text { Fluffy mycelium growth with } \\
\text { somewhat loose sub aerial hyphae. }\end{array}$ & $\begin{array}{l}\text { Undulate/ } \\
\text { Wavy }\end{array}$ & Irregular \\
\hline 14 & $\mathrm{Cg}-14$ & $\begin{array}{l}\text { Pinkish } \\
\text { gray }\end{array}$ & Creamy yellow & $\begin{array}{l}\text { Fluffy mycelium with partially } \\
\text { submerged growth. }\end{array}$ & $\begin{array}{l}\text { Undulate/ } \\
\text { Wavy }\end{array}$ & Irregular \\
\hline
\end{tabular}

Colony characters (colour, colour at reverse, distinct feature, margin and shape)

There was great deal of variation in the colony characters within $C$. gloeosporioides isolates. The colony colour was the most variable factor and none of the isolate was found to be identical with each other. The colonies of all isolates were initially white later gaining differential colour shades upon aging. The most predominant colour was creamy white to gray with various intermediate shades. While in case of colony colour at reverse, most of the isolates had dark gray to black colour with slightly different shades. Out of 14 isolates, eight isolates (viz., Cg-3, Cg-4, Cg-6, Cg-8, Cg-9, Cg-10, Cg-13 and Cg-14) had fluffy mycelium growth, while that of six isolates (viz., $\mathrm{Cg}-1$, $\mathrm{Cg}-2, \mathrm{Cg}-5, \mathrm{Cg}-7, \mathrm{Cg}-11$, and $\mathrm{Cg}-12$ ) had tight mycelium growth.

Isolates (viz., Cg-1, Cg-2, Cg-3, Cg-4, Cg-5, $\mathrm{Cg}-10, \mathrm{Cg}-11$ and $\mathrm{Cg}-12$ ) had entire margin with regular shape. Entire margin with irregular shape of colonies were noticed in the isolates $\mathrm{Cg}-7$ and $\mathrm{Cg}-8$ respectively. While that of $\mathrm{Cg}-6$, $\mathrm{Cg}-9, \mathrm{Cg}-13$ and $\mathrm{Cg}-14$ had undulate or wavy margin with irregular shaped colonies. These results show the similar trends as that reported by Fokunang et al., (2000), Joshi (2008), Chowdappa et al., (2012), Adhipathi et al., (2013) and Kumar et al., (2015) while studying the colony characters of $C$. gloeosporioides infecting different crops (Table 8).

\section{References}

Abnang, M. M., R. Asiedu, P. Hoffmann, G. A. Wolf, H. D. Mignouna and S. Winter, 2006. Pathogenic and genetic variability among Colletotrichum gloeosporioides isolates from yam hosts in the agroecological zones in Nigeria. $J$. Phytopath. 154: 51-61.

Adhipathi, P., S. Nakkeeran and A. Chandrasekaran, 2013. Morphological characterization and molecular phylogeny of Colletotrichum gloeosporioides causing leaf spot disease of turmeric. The Bioscan, 8 (1): 331 - 337.

Aldenderfer, M. S. and R. K. Blashfield, 1984. Cluster analysis SAGE pub. London, pp. 34-44.

Bailey, J. A., R. J. O'connell, R. J. Pring and C. Nash, 1992.Infection strategies of Colletotrichum spp. In: Colletotrichum Biology, Pathology and Control, CAB International, Wallingford, UK., pp: 88- 
120.

Chowdappa, P., C. S. Chethana, Bharghavi, R., Sandhya, H. and R. J. Pant, 2012.Morphological and molecular characterization of Colletotrichum gloeosporioides (Penz) Sac. Isolates causing anthracnose of orchids in India, Biotechnol. Bioinf. Bioeng, 2(1): $567-$ 572.

Dodd, J. C., A. Estrada and M. J. Jeger, 1992.Epidemiology of Colletotrichum gloeosporioides in the tropics. In: Colletotrichum Biology, Pathology and Control, CAB International, Wallingford, UK., pp: $308-325$.

Fokunang, C. N., A. G. O. Dixon, C. N. Akem and T. Ikotun, 2000.Cultural, morphological and pathogenic variability in Colletotrichum gloeosporioides f.sp. Manihotis isolates from cassava (Manihotes culenta) in Nigeria. Pakistan Journal of Biological Sciences, 3(4): 542 $-546$.

Gaikwad, A. P. and D. M. Sawant, 2005. Variability on morphological characters of C. gloeosporioides isolates from custard apple. J. Mycol. Pl. Pathol. 35(1): $80-84$.

Hasabnis, S. N. 1984. Studies on storage rot of mango (Mangifera indicaL.) fruits caused by $C$. gloeosporioides (Penz) Penz. And Sacc. And Botryodiplodiat heobromae. A M.Sc. (Agri) Thesis, BSKKV Dapoli, Maharashtra, India.

Joshi, M. S., 2008. Variability studies on Colletotrichum gloeosporioides Penz. infecting fruit crops. Ph.D. Thesis submitted to M. P. K. V., Rahuri.

Korade, B. B., D. R. Pawar and M. S. Joshi, 2001.Anthracnose disease of spider lily. J. Maharashtra Agric. Univ. 26(1): $70-$
71.

Kumar, S., Vineeta Singh and RuchiGarg, 2015.Cultural and morphological variability in Colletotrichum gloeosporioides causing anthracnose disease. International Journal of Current Microbiology and Applied Sciences. 4(2): $243-250$.

Lopez, A. M. Q. and J. A. Lucas, 2010.Colletotrichum isolates related to anthracnose of cashew trees in brazil: Morphological and Molecular description using LSU rDNA Sequences. Brazilian archives of biology and technology. 53(4): 741-752.

Manandhar, J. B., G. L. Hartman and T. C. Wang, 1995. Anthracnose development of pepper fruits inoculated with Colletotrichum gloeosporioides. Plant Disease, 79: 380-383.

Mathur, K., Thakur, R. P. and Rao, V. P. 2001. Characterization of Colletotrichum graminicola population from a sorghum hybrid CSH-9 for morphological and pathogenic variability. Indian Phytopath.54(3): 299-303.

Phoulivong, S., L. Cai, H. Chen, E. McKenzie, K. Abdelsalam, E. Chukeatirote and K. D. Hyde, 2010. Colletotrichum gloeosporioides is not a common pathogen on tropical fruits, Fungal Diversity, 44: 33 - 43.

Rohana, H. T., Wijesekara and D. K. Agarwal, 2006. Taxonomic studies on five species of Colletotrichum. Indian Phytopath. 5(2): $203-209$.

Talhinhas, P., S. Sreenivasprasad, S. Nevesmartins and J. oliveria, 2005.Molecular and phenotypic analysis of diverse C. gloeosporoides. Appl. and Envt.Microbiology. 71(6): 2987 - 2998.

\section{How to cite this article:}

Bandgar, M.S., B.G. Barhate and Raghuwanshi, K.S. 2018. Morphological Variation among Different Isolates of Colletotrichum gloeosporioides Isolated from Various Crops in Western Maharashtra, India. Int.J.Curr.Microbiol.App.Sci. 7(02): 2072-2084.

doi: https://doi.org/10.20546/ijcmas.2018.702.247 